\title{
FORMATION AND EVOLUTION OF STRUCTURE-PHASE STATES IN RAILS AFTER DRAWN RESOURCE
}

\author{
V. E. Gromov ${ }^{1 *}$, K. V. Morozov ${ }^{1}$, Yu. F. Ivanov ${ }^{2,3}$, K. V. Aksenova ${ }^{1}$, \\ O. A. Peregudov ${ }^{1}$, A. P. Semin ${ }^{1}$ \\ ${ }^{1}$ Siberian State Industrial University, 42 Kirova Str., Novokuznetsk, 654007, Russian Federation \\ ${ }^{2}$ Institute of High Current Electronics, Siberian Branch of the Russian Academy of Sciences, 2/3 Akademicheskii ave., \\ Tomsk, 634055, Russian Federation \\ ${ }^{3}$ National Research Tomsk Polytechnic University, 30 Lenina ave., Tomsk, 634050, Russian Federation
}

*Corresponding author. E-mail: gromov@physics.sibsiu.ru; address for correspondence: ul. Kirova, 42, 654007, Novokuznetsk, Russian Federation. Tel. +7 38437843 66; fax +7 3843465792

By optic and transmission electron microscopy, the regularities of the transformation of structural-phase states, the defective substructure of the rail surface layer to the depth of $10 \mathrm{~mm}$ under long-term operation (passed gross tonnage 500 and $1000 \mathrm{mln}$ ton) are determined. In the initial state the structure is presented by perlite grains with predominantly lamellar morphology, grains of a ferrite-carbide mixture and structurally free ferrite grains. It is shown that operation of rail steel is accompanied by a complete failure of lamellar pearlite grains in the $15 \mu \mathrm{m}$ thick surface layer and the formation of a ferrite-carbide mixture with nano-size particles. The strain-induced transformation of steel leads to the increase in the scalar and excessive density of dislocations, the curvature-torsion value of the crystal lattice and the amplitude of internal stress fields.

Keywords: structure, phase composition, surface, rails, operation, dislocation density.

DOI: $10.17804 / 2410-9908.2016 .1 .038-044$

\section{Introduction}

The increase in the density of freight traffic and the intensity of movement on modern railways leads to the quick rail failure for many reasons, including the contact-fatigue damages. Up to 15 percent of all rails removed in single replacement have inadmissible standards for wear and crumpling [1]. Apart from practical interest, the problem of rail damage is the subject of particular attention of specialists in the field of physical material science [2].

A long-term rail operation is accompanied by a sufficient change in the structure and properties of the surface layer of the material. The understanding of the processes occurring in the steel in this case is one of the important conditions of controlling the state of the material, and it allows one to predict the operational capabilities of rails. Taking into consideration the increasing growth of railway traffic with the simultaneous increase in unit load on axis tread surface contact and the average rate of movement, the establishment of the nature and regularities of structure, phase composition and defective substructure formation in the surface layers of a rail head in operation is a topical problem [2].

The aim of the research is to analyze the results of studying the rail structure, phase composition and defective substructure formation under long-term operation.

\section{Materials and methods of research}

Samples of rails whose properties and elemental composition are governed by GOST (Russian Standard GOST P 51685 - 2000) were used as a test material (table 1). Samples of rail steel were cut from the article in the initial state and after operation on a railway (passed gross tonnage 500 and $1000 \mathrm{mln}$ ton). The phase composition and state of the defective surface substructure and the near-surface layer of the rolling zone of the rail were analyzed. The metal structure was investigated by transmission diffraction (method of thin foils) electron microscopy (JEM-2100F, JEOL) 
$[3,4]$. Foils were made by electrolytic thinning of plates cut by the electrospark method on the immediate surface of rolling and at a distance of $2 \mathrm{~mm}$ and $10 \mathrm{~mm}$ from the surface of rolling.

Table 1 - Composition of rail steel (wt.\%)

\begin{tabular}{|c|c|c|c|c|c|c|c|c|c|}
\hline $\mathrm{C}$ & $\mathrm{Mn}$ & $\mathrm{Si}$ & $\mathrm{Cr}$ & $\mathrm{Ni}$ & $\mathrm{Al}$ & $\mathrm{V}$ & $\mathrm{N}$ & $\mathrm{S}$ & $\mathrm{P}$ \\
\hline 0.77 & 0.87 & 0.34 & 0.08 & 0.06 & 0.08 & 0.08 & 0.01 & 0.022 & 0.081 \\
\hline
\end{tabular}

\section{Results of research and discussion}

The rail structure before operation as in [2] is presented by pearlite grains of lamellar morphology (Fig. 1, a), by grains of structurally free ferrite without carbide phase particles in volume (Fig. 1,b) and ferrite grains, in the volume of which cementite particles of various shapes (grains of ferrite-carbide mixture) are observed (Fig. 1,c). The basic structural constituents of steel are grains of lamellar pearlite (volume fraction $\sim 75 \%$ ).

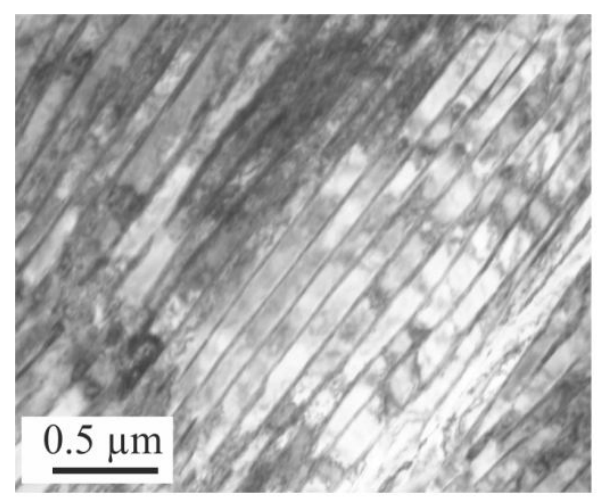

$a$

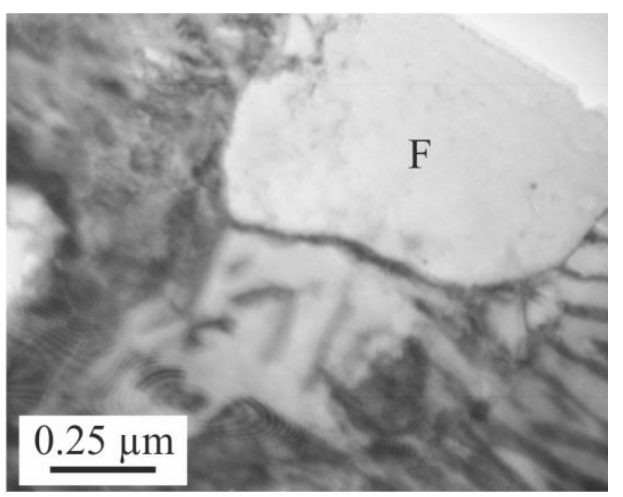

$b$

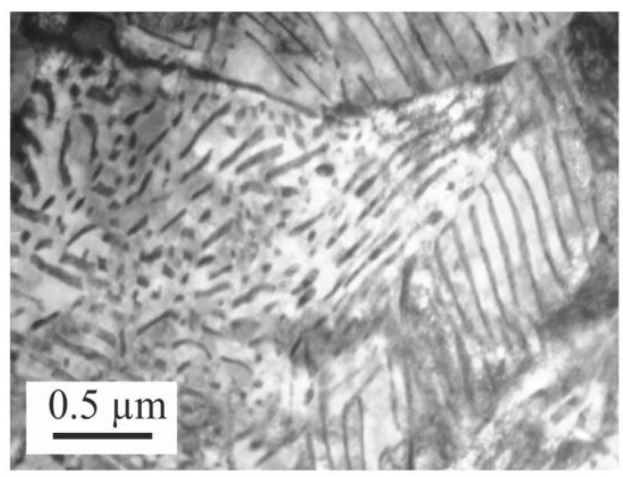

$c$

Fig. 1. Electron microscope image of the rail structure; in $(b) \mathrm{F}$ is the grain of structurally free ferrite

The lamellar pearlite of rail steel is characterized by the presence of various imperfections: ferrite bridges (sections of ferrite dividing a cementite plate) are observed; cementite plates are bended, non-parallel to each other and having aggregates of different types. By dark-field analysis, the defective substructure of the cementite plates is revealed. Namely, cementite plates are divided into fragments from 30 to $50 \mathrm{~nm}$ in size.

In grains of structurally free ferrite, the dislocation substructure in the form of chaotically distributed dislocations is observed; in pearlite grains (namely, in ferrite plates) it is a netlike substructure. The scalar density of dislocations in ferrite grains $\left\langle\rho>=3.2 * 10^{10} \mathrm{~cm}^{-2}\right.$, in pearlite grains $-<\rho>=4.2 * 10^{10} \mathrm{~cm}^{-2}$. The scalar density of dislocations reaches the maximum value near globular 
particles of the carbide phase, and it measures $\sim 8^{*} 10^{10} \mathrm{~cm}^{-2}$. The methods of scalar dislocation density were presented in [2-4].

The degree of structural change depends on the conditions of rail operation. The passed tonnage $500 \mathrm{mln}$ ton leads to full transformation and failure of lamellar pearlite structure in the surface layer of the rails. In the volume of pearlite grains, a structure with quasi-homogeneous distribution of carbide phase particles of round shape is formed, the average sizes of the particles being $17.5 \mathrm{~nm}$ (Fig. 2,a). The arrangement of cementite plates is guessed by the ordered arrangement of nanosize particles and a darker contrast on the image of the grain structure (Fig. 2, $a$, plates are designated by arrows). In the volume of grains of structurally free ferrite, steel deformation results in the formation of a band substructure (Fig. 2, $c-d$ ). The width of the bands varies between 30 and $50 \mathrm{~nm}$. The microelectron diffraction patterns obtained from the analogous structure have a quasi-circular structure (Fig. 2,c). In most cases, the reflections have azimuthal broadening, and this allows one to evaluate the azimuthal component of the full grain-boundary angle of substructure elements [4]. The analysis of the electron diffraction patterns carried out in such a manner has shown that, on the average, the value of the azimuthal component of the full grain-boundary angle measures 13 degrees.

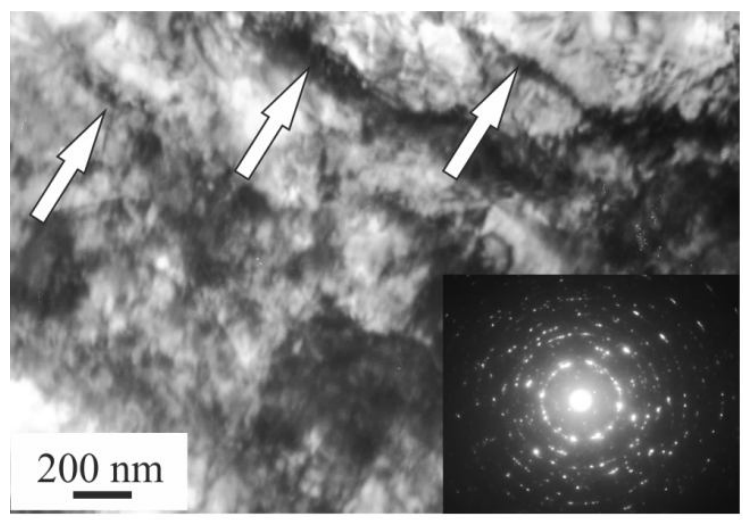

$a$

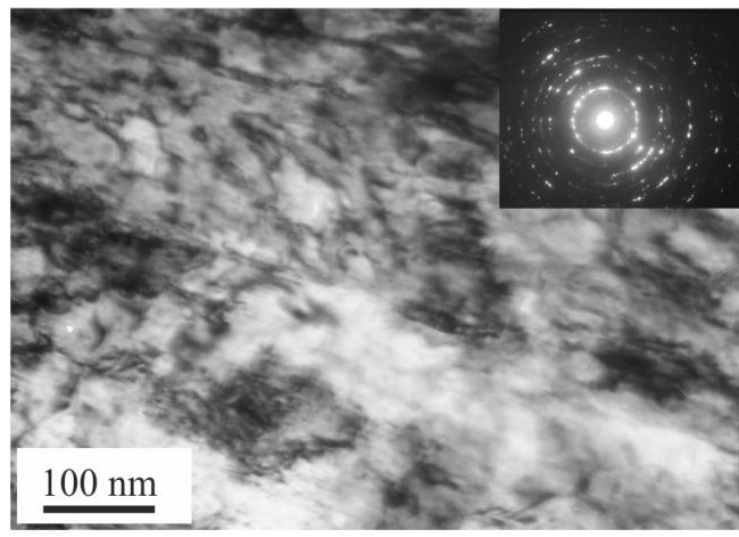

$c$

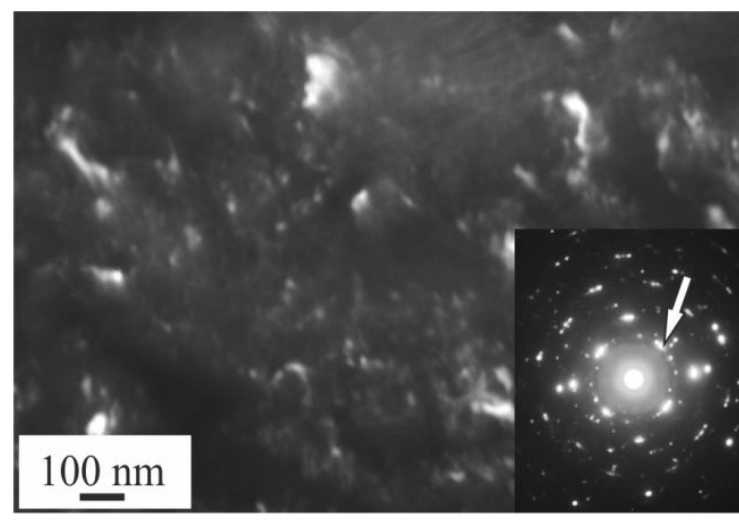

$b$

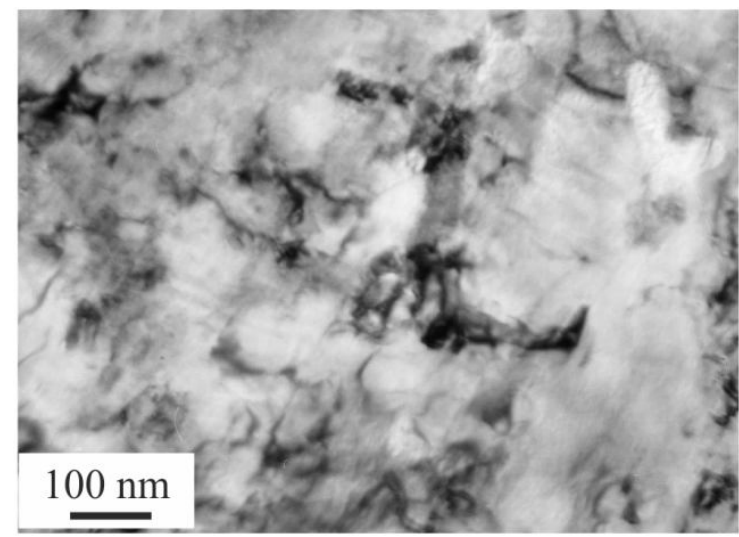

$d$

Fig. 2. Electron microscope image of the structure being formed in the rail surface layer after gross $500 \mathrm{mln}$ ton; $a, c, d$ - light fields; $b$ - dark field obtained in the reflections [110] $\alpha-\mathrm{Fe}+[102] \mathrm{Fe}_{3} \mathrm{C}$; in $a, b, c$ - microelectron diffraction patterns. The arrows in $(a)$ designate the locations of cementite plates failed under rail operation; in $(b)$ - the reflection in which the dark field was obtained

Following the operation (passed tonnage $500 \mathrm{mln}$ ton), the steel structure changes significantly in the layer adjacent to the surface of rolling. First, fragmentation of the cementite plates of pearlite colonies is revealed. Second, the cementite plates are cut into separate disoriented particles, 
as indicated by the quasi-circular arrangement of cementite reflections in the microelectron diffraction patterns obtained from the plates (Fig. 3, $a-b$ ). The particle sizes vary within $30-40 \mathrm{~nm}$. Third, the cementite particles are detected in the volume of ferrite grains and in the volume of the ferrite plates of pearlite colonies (Fig. 3,c-d). These facts can be indicative of the occurrence of two competitive processes under operating conditions. Namely, (1) the process of cementite particle cutting followed by their carrying out in the volume of ferrite grains or plates (in the structure of pearlite); (2) the process of cutting followed by the dissolution of the cementite particles, the transition of carbon atoms on dislocations (in Cottrell atmospheres), the transfer of the carbon atoms by the dislocations into the volume of ferrite grains (or plates) followed by the second formation of nanosize cementite particles. Other possible transformation mechanisms of the carbide subsystem in rail steel were analyzed in [5-13].

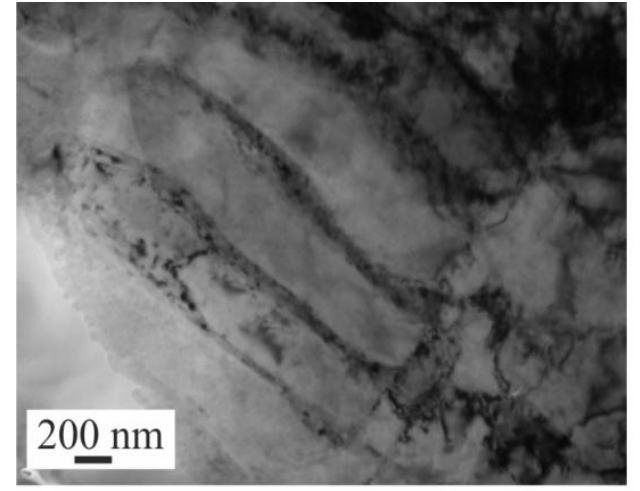

$a$

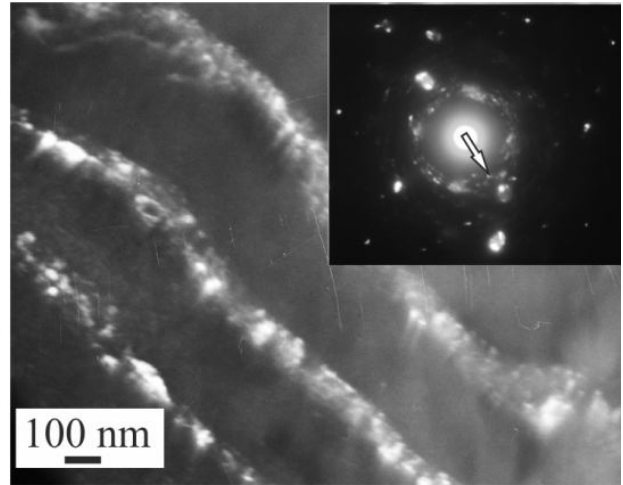

$b$

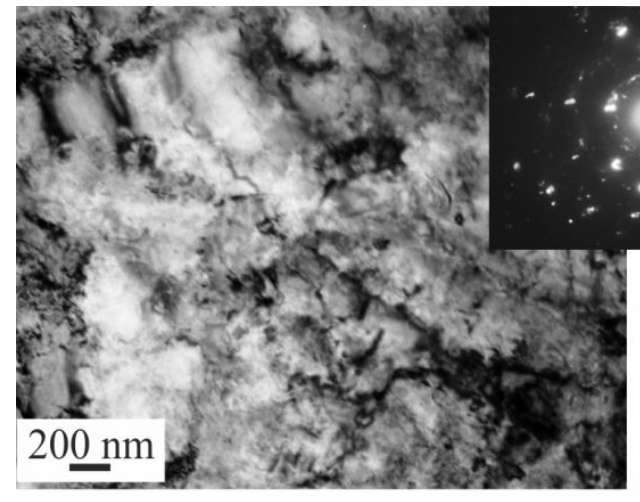

c

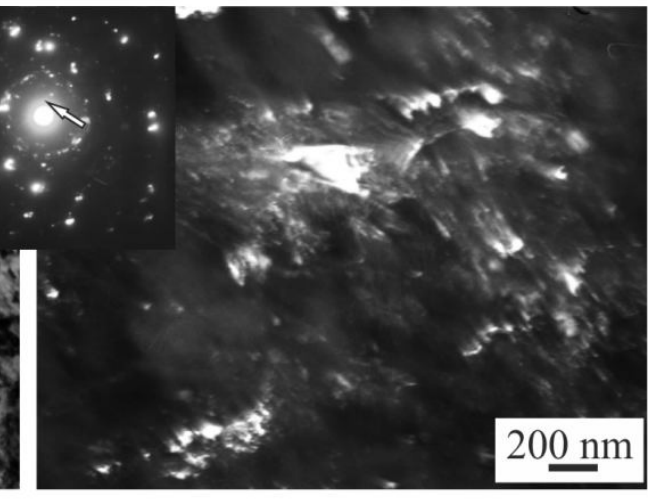

$d$

Fig. 3. Electron microscope image of the structure of the rail steel layer on the contact surface: $(a, c)$ - bright field; $(b, d)$ - dark field obtained in the reflections [031] $\mathrm{Fe}_{3} \mathrm{C}$ and [211] $\mathrm{Fe}_{3} \mathrm{C}$; electron microdiffraction patterns; the arrows indicate the reflections corresponding to the dark fields

The service of rails is accompanied by an appreciable increase in the scalar density of dislocations having attained the value of $\approx 10 * 10^{10} \mathrm{~cm}^{-2}$ at passed tonnage $1000 \mathrm{mln}$ ton. Simultaneously with the growth of the scalar density of dislocations, an increase in the internal fields of stresses is noted. The presence of them is detected, as mentioned above, by the presence of bend extinction contours. When analyzing the location of the contours in the steel structure, One can note that the sources of the stress fields are interfaces - intraphase (interfaces of grains, subgrains, fragments) and interphase boundaries (interphase of $\alpha$-phase and cementite).

It has been established as a result of the investigations that stress concentrators in the steel under study are interfaces of the cementite plates of pearlite grains, interfaces of pearlite grains and ferrite grains. In this case, the contour initiates from the interface of the plate and/or the grains. The 
sources of the stress fields are very often the particles of the second phase located along the boundaries and in the volume of grains.

The bending of the material crystal lattice may be, first, pure elastic one created by stress fields accumulated due to the incompatibility of deformation, for example, polycrystal grains [14], lamellar material to nondeformable particles [15]. The sources of the stress fields of elastic origin initiating mainly under uniform deformation of the material are the junctions and boundaries of polycrystal grains, disperse nondeformable particles, in some cases - cracks [16]. Second, the bending may be plastic if the bend is created by dislocation charges, that is, excess density of dislocations localized in some volume of the material, and third, the bending may be elastic-plastic when both sources of the fields are present in the material.

The procedure of evaluating the internal stress fields along the corresponding extinction contours consists in determining the curvature-torsion of the crystal lattice. For this purpose, either the rate of displacement of the extinction contour under the changes of the goniometer slope angle or the width of the extinction contour $[2,17]$ is measured.

The testing assessments carried out on hardened steels, as well as steels subjected to different degrees and types of deformation [2], have shown that reasonable assessments of the value of internal stress fields could be done using the following relationship:

$$
\sigma_{\tau}=G t \frac{\partial \varphi}{\partial \ell} \approx 10^{-2} G \frac{t}{h}
$$

where $\mathrm{h}$ is the transverse size of the bend extinction contour; $\mathrm{t}$ is foil width; $\mathrm{G}$ is the shear modulus of steel.

Thus, the morphology of bend extinction contours characterizes the gradient of the curvature-torsion of the material lattice, the value of the transverse size of the contours - the amplitude of the curvature-torsion of the crystal lattice.

The capacity of the bend extinction contour (internal stress fields generated by this contour) is characterized by its transverse size - the less are the transverse sizes of the contour, the higher is the amplitude of the internal stress fields $[2,4]$. Using this characteristic, one can note that the stress fields of maximum amplitude are formed by an interface particle/matrix (Table 2).

Table 2 - Values of long range stress fields

\begin{tabular}{|c|c|c|}
\hline Stress concentrators & $\begin{array}{c}\text { Width of bend extinction } \\
\text { contour, [nm] }\end{array}$ & $\begin{array}{c}\text { Values of internal stress } \\
\text { fields, [GPa] }\end{array}$ \\
\hline Boundaries of pearlite grains & $170-300$ & $0.4-0.8$ \\
\hline $\begin{array}{c}\text { Boundaries of ferrite and pearlite } \\
\text { grains }\end{array}$ & $150-200$ & $0.5-0.9$ \\
\hline $\begin{array}{c}\text { Interphase boundary of globular } \\
\text { cementite particle and ferrite matrix }\end{array}$ & $70-100$ & $1.6-2.3$ \\
\hline
\end{tabular}

\section{Conclusion}

The structure, phase composition and defective substructure of rails along the central axis to $10 \mathrm{~mm}$ depth are studied by optic and transmission electron diffraction microscopy. It has been found that rail operating conditions result in the formation of a multilayer structure. The surface layer up to $20 \mu \mathrm{m}$ thick has a multiphase and submicrocrystalline structure.

The rail operating conditions (passed tonnage $500 \mathrm{mln}$ ton) result in a complete failure of lamellar pearlite grains in the surface layer up to $4 \mu \mathrm{m}$ thick and the formation of a ferrite-carbide 
mixture with nanosize particles of a carbide mixture. The increase in the passed tonnage up to 1000 mln ton is accompanied by the growth of cracking in the surface layer with a fractured structure of lamellar pearlite. The strain-induced transformation of steel is accompanied by an increase in the scalar and excessive density of dislocations, the curvature-torsion value of the crystal lattice and the amplitude of internal stress fields.

\section{Acknowledgments}

The research is partially financed by the Russian Science Foundation (project number 15-12-00010).

\section{References}

1. Shur E.A. Povrezhdenie relsov [Failure of Rails]. Moscow, Intext Publ., 2012, 192 p. (In Russian).

2. Gromov V.E., Yuriev A.B., Morozov K.V., Ivanov Yu.F. Mikrostruktura zakalennykh relsov [Microstructure of Hardened Rails]. Novokuznetsk, Inter-Kuzbass Publ., 2014, 213 p. (In Russian).

3. Thomas G., Gorindge M.J. Prosvechivayushchaya elektronnaya mikroskopiya materialov [Transmission Electron Microscopy of Materials]. Moscow, Intekst Publ., 1983, 320 p. (In Russian).

4. Hirsch P.B., Howie A., Nicholson R.B., Pashley D.W., Whelan M.J. Elektronnaya mikroskopiya tonkikh kristallov [Electron Microscopy of Thin Crystals]. Melbourne, Krieger Publishing Co., 1977, 574 p.

5. Ivanisenko Yu., Fecht H.J. Microstructure modification in the Surface Layers of Railway Rails and Wheels. Steel Tech., 2008, vol. 3, iss. 1, pp. 19-23.

6. Ivanisenko Yu., Maclaren I., Souvage X., Valiev R.Z., Fecht H.J. Shear-induced $\alpha \rightarrow \gamma$ transformation in nanoscale Fe-C composite. Acta Materialia, 2006, vol. 54, iss. 6, pp. 1659-1669. DOI: 10.1016/j.actamat.2005.11.034.

7. Ning Jiang-li, Courtois-Manara E., Kormanaeva L., Ganeev A.V., Valiev R.Z., Kubel C., Ivanisenko $\mathrm{Yu}$. Tensile properties and work hardening behaviors of ultrafine grained carbon steel and pure iron processed by warm high pressure torsion. Material Science and Engineering: A, 2013, vol. 581, pp. 8-15. DOI: 10.1016/j.msea.2013.05.008.

8. Gavriljuk V.G. Decomposition of cementite in pearlitic steel due to plastic deformation. Material Science and Engineering: A, 2003, vol. 345, iss. 1-2, pp. 81-89. DOI: 10.1016/S09215093(02)00358-1.

9. Li Y.J., Choi P., Bochers C., Westerkamp S., Goto S., Raabe D., Kirchheim R. Atomic-scale mechanisms of deformation-induced cementite decomposition in pearlite. Acta Materialia, 2011, vol. 59, iss. 10, pp. 3965-3977. DOI: 10.1016/j.actamat.2011.03.022.

10. Ivanisenko Yu., Wunderlich R.K., Valiev R.Z., Fecht H.-J. Annealing behavior of nanostructured carbon steel produced by severe plastic deformation. Scripta Materialia, 2003, vol. 49, iss. 10. pp. 947-952. DOI: 10.1016/S1359-6462(03)00478-0.

11. MacLaren I., Ivanisenko Yu., Fecht H.-J., Sauvage X., Valiev R.Z. Early stages of nanostructuring of a pearlitic steel by high pressure torsion deformation. In: Y.T. Zhu et al., eds. Ultrafine Grained Materials-IV, Proceedings of a symposium at the 2006 Annual Meeting, San Antonio, Texas, March 12-16, 2006, Warendale, Pensylvania, TMS, 2006, pp. 1-6.

12. Ivanisenko Yu., Lojkowski W., Fecht H.-J. Stress- and Strain Induced Phase Transformations in Pearlitic Steels. Materials Science Forum, 2007, vol. 539-543 (part 5), pp. 4681-4686.

13. Ivanisenko Yu., Lojkowski W., Valiev R.Z., Fecht H.-J. The mechanism of formation of nanostructure and dissolution of cementite in a pearlitic steel during high pressure torsion. Acta Materialia, 2003, vol. 51, iss. 18, pp. 5555-5570. DOI: 10.1016/S1359-6454(03)00419-1. 
14. Panin V.E., Likhachev V.A., Grinyaev Yu. Strukturnyye urovni deformatsii tverdykh tel [Structural Levels of Deformation of Solids]. Novosibirsk, Nauka Publ., 1985, 229 p. (In Russian).

15. Rybin V.V. Bolshiye plasticheskiye deformatsii $i$ razrusheniye metallov [Large Plastic Deformations and Fracture of Metals]. Moscow, Metallurgiya Publ., 1986, 224 p. (In Russian).

16. Eshelby J. Kontinualnaya teoriya dislokatsiy [The Continuum Theory of Lattice Defects]. Moscow, Izdatelstvo Inostrannoy Literatury Publ., 1963, 247 p. (In Russian).

17. Gromov V.E., Kozlov E.V., Bazaikin V.I., Tsellermaer V.Ya., Ivanov Yu.F., Ignatenko L.N., Popova N.V., Chinokalov V.Ya., Poltoratsky L.M., Zakirov D.M. Fizika i mekhanika volocheniya $i$ obyomnoy shtampovki [Physics and Mechanics of Drawing and Die Forging]. Moscow, Nedra Publ., 1997, 293 p. (In Russian). 